\title{
Особенности языка памятников деловой письменности московской руси (на материале явочных челобитных XVII века)
}

\author{
Language structure of submission petitions \\ of the 17th century
}

\author{
Елена Чащина \\ Institute of Linguistics, Adam Mickiewicz University \\ ul. Międzychodzka 5, 60-371 Poznań, POLAND
}

\begin{abstract}
The article presents the language structure of petitions of the 17th century and analyses structural and formal features of these documents. A special attention is given to the analyses of standardized documents included in the beginning and the end of the document (entitling, vassalage, petitioning formulas, etc.) The informative part includes the description of thrashings, robberies etc, and the formulas and collocations are also showed there up. But considerable attention is given to the analyses of the folk-and-spoken language elements the use of which results from the specific reasons including the conditions of the informative and psychological features, etc.
\end{abstract}

Деловая письменность занимает особое место в решении многих задач, связанных с изучением процесса становления и развития русского литературного языка нового типа. Возрастающая роль приказного делопроизводства в период XVI - XVII веков, а следовательно, все более расширяющаяся сфера применения делового языка обусловили огромное жанровое и функциональное разнообразие деловой письменности. В связи с этим возникает настоятельная необходимость дифференцированного подхода к исследованию конкретных видов деловых памятников, так как в них в разной степени находят отражение те или иные лексические, грамматические элементы книжно-письменного и народноразговорного языка.

Особый интерес в этом отношении вызывают явочные челобитные, отличающиеся разнообразным содержанием и языковым составом. Рассмотрим особенности структуры и языка этих документов.

Характерной особенностью этих деловых текстов является рамочное расположение стандартизованных элементов, входящих, как правило в состав начала и конца документа. В связи с этим обстоятельством исследователи противопоставляют лексику, составляющую формуляр документа, лексике, которая раскрывает содержание акта. [Волков 1972: 10] 
Внутриформулярная часть челобитных нередко представляет собой живой рассказ о различных событиях, обстоятельствах и фактах.

В структуре явочных челобитных выделяются три части: I. начальный протокол, содержавший 1) формулу общения к адресату (кому): Царю государю и великому князю..., 2) формулу челобитья: бьет челом и являет, 3) сведения об адресате: сирота твой.., холоп твой $и$ m.д ... 4) указание на то лицо, на которое челобитник обращается с жалобой:

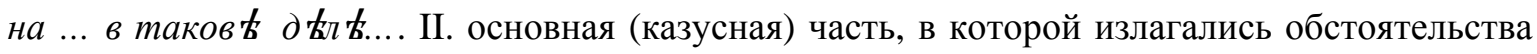
дела, мотивы и основания обращения с жалобой . III. просительная часть: милосердный государь изарь и великий князь...пожалуй меня холопа своего, вели, государь, мое челобитье и явку записать; IV. конечный протокол: иарь государь, смилуйся, пожалуй.

В качестве примера приведем один из документов, явку в Холмогорскую таможенную избу куростровца Фомы Ушакова на Матфея Окулова в бое и издевательстве над ним в Яковлевской трапезе (в сокращении):

I. 1. Царю государю и великому князю Алекс ъю Михайловичю всеа Великія и Малыя и Б

I. 2. бьеть челомъ и являеть

I. 3. сирота твой Куростровской волости өомка Павловъ Ушаковъ

I. 4. Куриовского посаду на Матюея Митрофанова Окулова.

II. Въ нын тинемъ, государь, во 182 году, іюля въ 31 день, будучи на Городкъ въ Яковлевской трапез ъ биль онъ Матюей меня, сироту твоего, и ув бчиль нахвально...

III. Милосердный государь иарь и великій князь Алекс ъй Михайловичъ всеа Великія и Малья и и Б Блья Росіи самодержещъ, пожалуй меня сироту своего, вели, государь, на Колмогорахъ таможенном избы головь Дороюею Мелиову съ товарыщи челобитье мое принять и записать.

IV. Царь государь, смилуйся, пожалуй. [АХУ, II 1674: 439-440].

Аналогичный состав встречается не во всех документах. Какие-либо из составляющих его частей могут отсутствовать, могут содержаться и другие. Кроме того, можно отметить вариативность конструкций, передающих то или иное содержание.

В начальном протоколе северновеликорусских явочных челобитных XVI - XVII в.в. использовались конструкции с расположением временного детерминанта в инициальной позиции: Лтта 7142, іюня в 5 день бьетъ челомъ и являетъ Митрошка Моисеевъ ... на Онанью Шамшурницина да на Парасью Меншикову дочерь на Рожневу Шевдениикіе волости в таков $\boldsymbol{k}$, господине, $\partial$ 加 $\boldsymbol{k}$ [АХУ, II 1634: 719, 439-440]. Аналогичные конструкции с временным детерминантом лета... были характерны для документов других видов (грамот, памятей и т.п.). Именно такой типичный зачин оказал влияние на оформление начального протокола челобитных. Позднее, со II трети XVII века, в документах данного вида используется формула изарю государю и великому князю...бьет челом и являет. Такая формула становится общепринятой, и иное оформление начального протокола встречается крайне редко.

Формула адресата содержит собственное имя того лица, к которому обращается челобитчик, а также его титулы. Состав царского титула в челобитных разных видов не был единообразным на протяжении всего рассматриваемого нами периода. Как отмечает С.С. Волков, формула титулования содержит элементы, различные по времени своего возникновения и отражает основные этапы развития верховной власти на Руси [Волков 1972: 32]. Так, до середины 80-х годов XVI века царский титул имеет следующий вид: 
Государю ицарю и великому князю Ивану Васильевичю всеа Русии. Приведем примеры такого титулования: Государю иарю и великому князю Ивану Васильевичю всеа Русіи [АЮБ, III, № 367, 1569]; Государю изарю и великому князю Өедору Ивановичю всеа Русіи [АЮБ, III, № 367, 1584]. С середины 80-х годов, как указывает автор, порядок слов в начале царского титула меняется и принимает следующий вид: Царю государю Федору Ивановичю всеа Русии. Именно такой порядок начальных элементов сохраняется и в XVII веке (В противовес широко употребительному в то время наименованию в воеводских отписках: Государю иарю и великому князю Ивану Васильевичю всеа Русии...). Например: Царю гсдрю и великому кнью Михайль өедоровичю всеа Рдси [МДБП, № 1-30, 1617-1638; АЮБ, III, №369, 1640]; Црю гсдрю и великому князю Алекс ъю Михайловичю всеа Рвсии [МДБП, № 34, 1645]. Причиной дальнейшего видоизменения титула послужило воссоединение Украины с Россией, и составная часть титула «всеа Руссии» заменяется на «всеа Великия и Малыя и Б Б九лья России самодержеи»: Црю гсдрю и великому князю Алексию Михайловичю всеа Великия и Малья и Б блыя Росіи самодержиу [МДБП, № 53-101, № 97, 1656-1675]; Црю гсдрю и великому кнзю Фешдору Алек қевичю всеа Великия и Малья и Бһлыя Росіи самодержиу [МДБП, № 102-114, 1676-1681]; Цремъ гсдремъ великимъ кнзем Іоанни

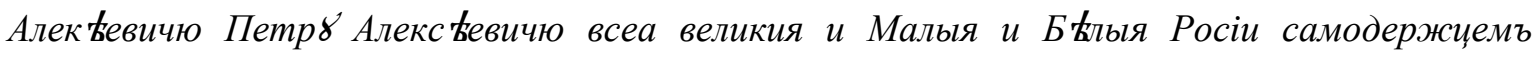
[ГААО, ф. 191, оп.2, № 235, 1683]. С середины 80-х годов XVII века начальные элементы царского титула дополняются вновь появившимся определением великий, что было, видимо, обусловлено укреплением самодержавной власти [Волков 1972: 32-33]. Например: Великомб гсдрю ирю і великомд кнзю Петря Алекс қевичю всеа Великия и Малья и Б қлыя Росіи самодержием [ГААО, ф. 191, оп.3, № 211, 1697; ф. 57, оп.2, № 390, 1697]; Великимъ гсдремь иремъ і великим кнземъ Иоанну Алек қевичю Петря Алекскевичю всеа Великия Малыя i Бъльья Росіи самодержиемъ [ГААО, ф. 191, оп.3, № 194, 1695; ф. 57, оп.2, т.I. № 381, 1695; АИ, V, № 209]; Титул царицы мог иметь такой вид: Гсдрне ирие в вликой княгин Лбкньяновн ' [МДБП, № 37, 1641]. Но традиционным элементом титула царицы было прилагательное благоверный: Гсдрне блгов қрной ирие и великой кнгине Евдакъе Лук(ья)новн ъ [МДБП, № 31, 1638]; Великимъ гсдремъ иремъ и великимъ кнземъ Иоанну Алекс Ћевичю Петр8 Алекс ъевичю и великой гсдрне блговерной ирвне и великой кнжне Союиі Але ъевне всеа Великия і Малыя и Б ълыл Росиі самодержием [МДБП, № 129, 1688].

В явочных челобитных в состав начального протокола, после указания адресата входит формула челобитья, представляющая собой сочетание бьет челом и являет с указанием имени челобитчика (или группы челобитчиков) и сообщением некоторых данных о нём (или о них): Царю государю і великому князю Михайлу Фёдоровичу всея Руси бьютъ челомь и являють сироты твои государевы Устюжского у ъзда Шолские волости крестьяне Девятка да Володка Өедовы д қти, да Сергушка Дмитревъ сынъ, да Матюшка Ульяновъ сынъ Момотовы. После чего следует казусная часть челобитной: $B ъ$ нынемнемъ, государь,...[АХУ, 3, №96, 1632]. В некоторых случаях в формуле челобитья используется и глагол плачется. Тогда эта формула выглядит так: бьет челом и плачется и являет... . Например: ...бьетъчеломъ и плачется и являеть сирота твоя государева Мишка Карповъ сынъ Новинского... [АХУ, ІІІ , № 238, 1663], бьютъ челомъ плачются и являютъ твои государевы богомолиь нищие черниьь... [АХУ, 3, № 57, 1628].

Названию имени челобитчика предшествует формула, выражающая вассальные отношения челобитчика к тому лицу, которому адресован документ. Такого рода формулы использовались в соответствии с тем социальным положением, которое занимал челобитчик. 
Так, у служилых людей разных сословий использовалась формула холоп твой (вам), у крестьян - сирота твой (ваш), раба (сирота) твоя (вама) - у женщин, священнослужители использовали формулу богомолеи твой (ваш), богомолица твоя (ваша) [Волков 1972: 44].

Формулы вассальной зависимости могли дополняться согласованными и несогласованными определениями, указывающими на то лицо, чьим поданным челобитчик является. Это могли быть прилагательные государев, царский, а также твой святительский, если речь идет о лице духовного звания: бьють челомъ и плачютца твоя Государева сирота Соли Камской староста Васка Елес Ћевъ сынъ Александровъ и во вс kxъ земскихъ посадскихъ и деревенскихъ крестьянъ м всто [АИ, II 230, 1609]; бьет челом и являеть твой святительской богомолецъ Ляменскихъ починковъ попъ өерапонтъ Івановъ [AXУ, III 215, 1658].

Челобитные эпохи смутного времени и междуцарствия, адресованные боярам и воеводам, не содержат многих элементов уничижительного характера, в том числе и формул вассальной зависимости. В челобитной монастырского крестьянина называние адресата звучит так: бьет челомъ и плачется Вяжитикого монастыря крестьянинець Толвуйскія волости Муратко Семеновъ Пустинъ [АЮ, 34, 1611]. Встречаются документы, где при полном отсутствии средств уничижительного характера даже имя собственное указывается в полной форме: Великіе Російскіе державы Московского государьства бояромъ и воеводамъ бьет челомъ и являетъ вдова Анна Оюонасьева жена Плохова Суздальского уезду [АЮ, 50, 1613].

Начальный протокол явочных челобитных содержит и указание на тех лиц, на которых жалуется челобитчик, вследствие чего формула челобитья дополняется предлогом на: бьёт челом и являет...на..., далее следует фиксация имени конкретного лица (лиц) и нередко определенной информации о них. Например: Царю государю і великому князю Михайлу Фёдоровичю всея Руси бьютъ челомъ и являють твои государевы нищие богомолиьы Устюга Великого Троечкого монастыря з Глед tна игуменъ Иона з братьею Устюга жъ Великого Архангилского монастыря на архимарита Паюнутья з братьею [АХУ, 3, № 137, 1636].

Кроме того, указанная выше формула нередко дополняется сочетанием в том..., которое позволяет перейти к изложению обстоятельств дела, например: Царю государю i великому князю Михаилу Федоровичю всея Руси бьет челомъ и являетъ сирота твой государевъ Устюжанинъ Богдашка Микиооровъ сынъ Прянишниковъ кузнецъ на Устюжескихъ на посадикихъ земскихъ судей на Оюонасья Іванова сына котелника съ товарыщи въ томъ:...(Далее следует казусная часть документа). [АХУ,3,№ 49, 1627].

В некоторых случаях с этой целью используется сочетание в таков $\boldsymbol{b} \partial \boldsymbol{k} л е: .$. . Например: Царю государю і великому князю Михаилу Федоровичю всея Руси бьет челомъ и являетъ сирота твой государевъ Устюжеского у ћезда Митрополья стану крестянинъ Оилка Григорьевъ сынъ Рожковской на брата своего родного на Терентья Григорьева сына Рожковского жъ въ таков ь $\partial$ 女ле...(АХУ,3,№ 167, 1639, там же № 57, 1628, № 60, 1628, №126, 1634). И только в одном случае зафиксировано сочетание о томъ: ... бъетъ челомъ и являеть сирота твой Черевковской волости крестьянинъ Гришка Щепинъ тое жъ волости на Іванна Харитонова сына Ступина о томъ... [АХУ, 3 ,№ 118, 1633].

В документах данного вида, содержащих жалобу на того или иного человека или группу людей, совершивших какие - либо противоправные действия (грабёж, насилие и т.д.), челобитчики при сообщении данного обстоятельства и при назывании конкретных лиц, как 
правило, воздерживаются от каких-нибудь определений и эпитетов негативного характера, они указывают только на место жительства и социальное положение, то есть на те сведения, которые формально являются необходимыми. Так в челобитной Томила Телминова на Михайла Стрижева, ограбившего его, читаем: ...бьетъ челомъ и являетъ сирота твой государевъ... на Михайла Иванова сына Стрижева, на Устюжанина на посадиково человъка Халеской волости крестьянинъ Томилко Ярао евъ сынъ Телминовъ...И далее в тексте: Въ прошломъ, государь, во 134-омъ году, о Петрове заговейне, стояль я Томилко y того Михайла на Устюге Великомъ на подворье, и тотъ, государь, Михайло меня покралъ... (перечисляются все пропавшие вещи). Такое оформление можно охарактеризовать как нейтральное. Но оно не всегда бывает таким. Нередко уже в состав начального протокола вводятся определения и однородные дополнения, которые характеризуют человека и совершенные им действия и в определённой степени являются оценочными. С этой точки зрения обращают внимание на себя следующие фрагменты: бветъ челомъ и являеть ...на силныхъ людей на Івана Дмитриева Зорина, на Івана Каме ъдова, на Игнатья Нагихъ. [АХУ, III, № 242, 1665], ... бьет челом и являетъ сирота твоя ... на Устюжанина на силного человъка на грабетчика на Кондратья Прокопьева сына Каренгина, прозвищемъ на Шероха [АХУ, №86, 1631], бъет челомъ и являетъ... на убойцовъ Устюга Великого Сухонсково стану на Максима Аоонасьевича сына Серебреникова деревни Шемякиной съ товарыщи [АХУ, № 79, 1641], бьеть челомь и являетъ ...тое жъ Пермогорские волости на поклепщиковъ и заговорщиковъ и ложныхъ челобитчиковъ на Пъянка Григоръева сына Ушакова да на Томила Тимоф қева сына Маркова... и иныхъ заговорщиковъ въ томъ... [АХУ, ІІІ, № 154, 1637]. В челобитной Устюжского крестьянина, сообщающего о поджоге, имена обидчиков обозначены нейтрально, но при этом используются специальные термины для называния группы людей, участвовавших в этом: ... бьетъ челомъ сирота твой... того же стану на Тита Устинова да на племянника его на Луку Фомина сына, да на...і на ихъ потаковщиковъ $i$ на заговорщиковъ, и на ставщиковъ [АХУ, III, № 103, 1632]. Примерно тоже находим в другом документе: являемъ государь, то же волости на Обакумка Тарасова сына з детми, на ихъ родъ и на заговорщиковъ [АХУ, 140, 1637].

В некоторых документах в начальном протоколе подчёркивается факт известности лиц, которые совершили незаконные противоправные действия. Так, в челобитной таможенного головы на Куму Бушуева с товарищами, обвиняемых в убийстве и грабеже, в начальном протоколе читаем: ... бъеть челомъ и являеть ... на в бдомыхъ воровъ на Коземку Бушуева съ товарыщи. И далее в тексте при назывании имени преступников обязательно присутствует существительное воры: В нынъшнемъ, государь, 168-омъ году, февраля противъ 17 числа въ ночь, при қзжали онь воры Коземка Бушуевъ, съ товарыщи къ намъ сиротамъ твоимъ въ деревню Подозерье воровски, разбоемъ.... A mъ въдомые воры Коземка съ товарыщи приведены были на Устюгъ въ сь қзжую избу... [АХУ, ІІІ, № 229, 1660]. Если же воры были неведомые, то указание на этих лиц в начальном протоколе может отсутствовать. Данная часть документа предстает в сокращённом виде. Например: Царю государю і великому князю Алекс ъю Михайловичю всея Великия Малья і Б блья Росси самодержиу, бьють челомь являють сироть твои Утмановские волости крестьяне Іванко Емельяновъ да Мартемьянко Михайловъ Котелниковы. Далее сразу же следует казусная часть: $B$ ъ нынешномъ, государь, во 169-мъ году, марта противъ дватиать седмаго числа въ ноче, 


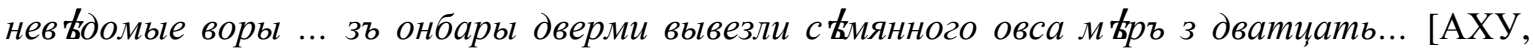
3, № 231, 1661].

В казусном разделе челобитной содержатся следующие части:

1) изложение жалобы челобитчика на какое-то лицо, подробное описание совершенных им действий (нанесение обид, оскорблений, увечий и других противозаконных действий);

2) сообщения об угрозах обидчика: да и впредь тот ...хвалится (похваляется) на меня + существительное творительного падежа (убийством, поклепом, патьбою, пожегом и т.п.);

3) предупреждение о возможном исполнении угроз: и будет мне случится смерть (поклеп, продажа) и те люди убойцы и супостаты.

Рассмотрим более подробно языковой состав казусного раздела челобитной. Изложение жалобы челобитчиком традиционно открывается указанием даты: $B$ прошлом, государь, во 153-м году привезли мы в Шую сто тринадиать рогож соли [КЧ, 3]; В нын тинемъ, государь, во 134-мъ году июля противъ 12-го числа въ ночи, покрали, государь, у меня Гришки лавку [AXУ, III 8, 1626]. В нынешнем, государь, во 136-м году марта в 16 день приезжал я в Шую торговать и взошел я к ним на кабак испить [КЧ, 3]. Но нередко в явочных челобитных фиксируется не цифровое обозначение даты, а называются наиболее важные даты религиозного календаря. В нынешнем, государь, во 136-м году в первое воскресенье великого поста приезжал, государь, я в Шую с хлебом торговать [КЧ, 8]; В прошломъ, государь, во 134-мъ году, о Петрове заговейне, стояль я Томилко у того Михайла ... на подворье лавку [АХУ, III 4, 1626]. В нын ъиномъ, государь, во 136-мъ году, угов ъвъ Петрова посту нед Һлю, съ суботы противъ воскресенія въ ноче сожгли, государь, ... нашу монастырскую мельнииу [АХУ, III 53, 1628]; В нын тинемъ, государь, въ 134-мъ году, после Велика дни Христова, въ Мироносицкую недћлю, збежсала, государь, у меня з двора сноха моя [АХУ, III 5, 1626]; В нын ниномъ, государь, во 135-мъ году, после Покрова Святой Богородищы, былъ язъ стареиъ Архипъ... [АХУ, ІІІ 33, 1627].

В некоторых документах изложение обстоятельств дела начиналось глаголом $\partial$ қялось: Дқялось, господине, л қта 7087, в Лазарево воскресеніе, посль обидн қй, зваль меня, господине, на пиръ Порома Василивъ сынъ Батурина [AXУ, II LXII 1579]; Дьялось, господа наши, нын жинего 112, въ Покровъ святей Богородичи, пошоль еслие, господа наши, къ

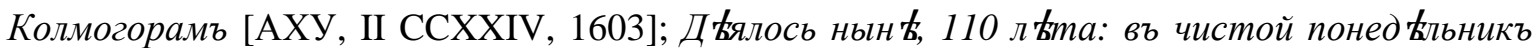
пошель если, господине, на Веригино и въ Ромамево купити ржи и скотиново корму. [АХУ, II IICCXVI 1602].

Статья, в которой челобитчик говорит о том, что его обидчик угрожает и впредь делами недобрыми, имеет довольно устойчивый лексический состав. Как правило, используется глагол хвалиться (похваляться), после чего следует перечисление обещаемых действий: убийством, грабежемъ и т.п.: Да и впредъ тоть Степанъ на меня Гришка похвалился убийствомъ и всякими делами недобрыми [АХУ, III 40, 1627]; Да и впредь онь на меня похвалились убийствомъ, и грабежемъ, и подметомъ, и поклепомъ, и всякими недобрыми д kльь [АХУ, III 66, 1629]; Да і впредь, государь, тоть Ларионъ да и з братомъ своимъ похвляется на насъ стариевъ и на слугъ монастырскихъ, и на кр ъстьянъ ...убийствомъ и поклепомъ, и подметомъ, и пожегомъ, і всякими недобрыми делами [АХУ, III 60, 1628]; i впредь, государь, $m \boldsymbol{t}$ люди Посп ъль съ товарыщи и съ своими родимщы и з заговорщики похваляютиа на меня попа и на братью и на скоть и на животь убийствомъ, и бесчинствомъ, и подметомъ, и поклепомъ и пожегомъ, $і$ всякими д қль лихими [АХУ, III 
55, 1628]; и впред похваляются тем же боем и грабежем, и смертным убойтвом, и подметом, и пожегою, и всякими лехими дель [КЧ, 93]; [АХУ, II CCCLII, 1649].

В некоторых случаях в данный фрагмент включались элементы разговорного характера: Да и впредь онъ Грибуша на меня Митрошку хвалитио всякимъ недобрымъ д ъломь, и напрасной продажей, и на меня убійствомъ, а я человъченко одинашно, на пашнишко волочюсь одинъ [АХУ, II 719, 1634]; Да и впредь тоть өедотъ хвалице на насъ, сиротъ твоихъ государевыхъ, всякими недобрыми д қль, татбой и разбоемъ и поклепомъ, и подметомъ, и застиеньемъ, и зар взаньемъ, и н тть намь сиротамъ оть него өедота ни проходу, ни про взду [AХУ, II CCCLIII, 1649].

Встречаются документы, в которых вместо хвалиться (похваляться) используются глаголы угрожать, уграживать: И впредь он мне угрожсает смертным убойством [КЧ

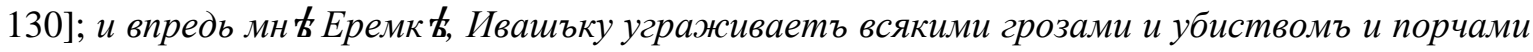
[АХУ, III 41, 1627]. В такого рода синонимах хвалиться (похваляться) и угрожать, угражсивать прослеживается функционально-стилистическая противопоставленность: угрожать представляло собой народно-разговорное слово, а хвалиться (похваляться) термин делового языка. [Майоров 1987: 7].

Формула - предупреждение о возможном исполнении угроз является довольно устойчивой по своему содержанию, но в ее оформлении и лексическом составе можно отметить некоторые варианты: 1) И будет, государь, то-то то-то случится, и те люди убойцы и супостаты и т.п. Например: И буде, государь, впредь мн ъ попу или братье моей ученится безв кстная смерть или животу нашему учинитца какая проруха, и m убойцы и супостаты [AХУ, III 55, 1628]; А что впредь мн ъ Томилку отъ того пономаря учинится убиство оть ево похвальныхъ речей, и онъ мн ъ убойца и впредь истець [АХУ, III 27, 1626]; Инд ь буде мн ъ Левке или брату моему учинитиа безв встная смерть или какая проруха ни буди, ино тоть Шорохъ убойца и душегубеиъ и грабежщыкъ [АХУ, III 37, 1627]. 2) И будет, государь, то-то то-то случится, и кроме того человека на себя супостата не знаю. Например: И будетъ что намъ случитиа которому безв ъсная смерть, и кроме того Зот kя, на собя супостата не знаемъ [АХУ, III 41, 1627]. 3) Третий вариант оформления имеет две разновидности: а) И будет, государь, то-то то-то случится, и кроме того человека на себя супостата не знаю: он мне супостат и убойцьл. Например: И будетъ, государь, надо мною какая безв қстная смерть учинитча, и окром қ, государь, его Шумила и брата его Прокопья на себя иныхъ супостать никто не в бдаю: он III 77, 1629]; И впредь, государь, какова надо мною незгода учинития, и я опричь того Роспуты Романова на себя супостата не знаю ... и во всяком недобромъ д қле тоть мн Pocnута супостать и убойца [АХУ, III 129, 1634]. б) И будет, государь, то-то то-то случится, те люди убойцы супостаты: кроме нихъ других супостат не знаю и не ведаю. Например: И будеть государь, мн ' Кирилку гдњ случится безв ксная смерть или скоту намему, ино тоть Семенъ и съ сыномь своимъ и убойць .... и опроч $\mathbf{k}$ государь, того Семена съ сыномъ, супостата на себя не знаю и не в ъдаю [АХУ, III 25, 1626]; И будетъ, государь, гд $\mathbf{b}$ мн $\mathbf{b}$ Мишке случится безв всная смерть или скотишку моему ... ино тоть, государь, Семейка съ сыномъ своимъ Степанкомъ мнъ Мишке и убойца и скотишку моему ... и опроч $\mathbf{k}$, государь, язъ Мишка того Семейки съ сыномъ супостата на себя не знаю и не в ъдаю [АХУ, III 45, 1627]; И будеть мн Васке где безвесная смерть случитиа, и тоть Оторой з братьями супостаты мн ъ и убойцы ... я Васка, опроч ихъ супостата не знаю на собя [АХУ, III 54, 1628]. 
Наблюдения над лексическим составом явочных челобитных позволяют сделать вывод о том, что он неоднороден. В тех случаях, когда речь идет о совершении каких-либо действий, их оценки, используются достаточно точные формулировки, отличающиеся устойчивым лексическим составом. Например, когда речь идет о хищении какого-либо имущества, используется наречие грабежем: а грабежемъ съ меня з головы схватиль шапку, по отласу по б қлому золотом шито ...[АХУ, III 86, 1631]; и шель въ казенную келью и коробью казенную разломаль, изъ коробьи денегъ казенныхъ грабежемъ выняль двадиать три рубля двъ гривнь ... а грабежемъ, государь, съ него сорвали кр ъсть серебряной ... [АХУ, III 60, 1628]; и взяли у меня у Микитки грабежемъ съ поварни св бзли четырнадцать бочекъ вина полные [АХУ, III 90, 1632]. Данная лексема употребляется также и в сочетании с наречиями самовольством, сильно и т.п., чем подчеркивается незаконный характер совершаемых действий: приещаль тоть попь Савинъ да диечекъ Тимоний со многими людми съ нев фдомыми ко мн ъ въ деревню на Павшино грабежемъ, и у клети замокъ сломали и взяли исъ клети своимъ само(во)лствомъ и грабежемъ однорядку да шапку, да шупунъ [АХУ, III 107, 1632]; онъ Шумило съ т tиъ своимъ братомъ съ Прокопьемъ ... унесли изъ дворишка силно грабежемъ чюжово платья и моего две рубашки золотомъ шить [АХУ, III 77, 1629]; Да оне жъ, государь, Олексиевы приказные съ половниками унесли грабежемъ и насильствомъ съ ослищь и съ огородовъ сто локоть полотенъ [АХУ, III 126, 1634]. Вариант: а меня сироту твоего т қиъ своимь грабителствомъ учиниль безъ сибирского промыслу и безъ торгу [АХУ, III 112, 1633]. Только в редких случаях встречаются нетрадиционные разговорные элементы: жена ево Анна съ половниками своими и съ потановщи(ки) своими жъ ... воровски украдомъ по чюжимь гумнамъ рожъ мою измолотила три овина безъ твоего великого государя указу [АХУ, III 245, 1665]; тоть человекъ мой Тренка Ермолаевъ з женою своею ... изъ дворенка моего сошелъ, не отрамався у меня холопа твоего, ... и платье, государь, и иную рухлядь пократчи поносиль съ собою [AXУ, III 81, 1630].

Факт противозаконности совершаемых действий может быть выражен с помощью наречия сильно: и тоть Миня съ товарыщи своими у насъ у меня Вешнячка и у товарищевъ моихъ, влад тть, сверхъ деловые записи, паменною землею сильно [АХУ, III 69, 1629]; тоть же Дмитрей з братиею порубал меня Якимка б қлочнымъ окладомь силно [АХУ, III 76, 1629]; и тое, государь, лошади мерина моего и по Сю пору не отдаетъ, владиетъ силно [АХУ, III 181, 1641]. Также употребляются слова своим самоволством, насильством и их сочетания: И тое твоей государевы службы они своимь самовольствомь служсть не похот вли [АХУ, III 202, 1652]; и тоть Дружина скотомъ своимъ въ поляхъ гобину мою всякую, рожь и ярь, травить да і въ пожняхь моихь своимъ насилствомъ, а нев бдомо почему. И тот, государь, Дружина, приходя къ моему двору деревни Заямькучья, насильствомь своимь двери у клевовъ сечеть [АХУ, III 70, 1629]; тоть же Дмитрей з братьею деревнишко мое порубали б флочнымъ окладомъ силно, самоволствомъ [АХУ, III 87, 1631]; тоть попь Петрь у Леонтья Ростовского чудотвориа у иеркви Божиі служить своимъ самоволствомъ безъ мирскихъ людей слова и хл ббъ емлетъ ружной насильствомъ же [АХУ, III 182, 1641]; и столбы и пов бть и переклады мои Сидорковы пос бкъ и оботесаль своимъ самоволством силно... И тоть Серьгий мою Сидоркову землю дворовую и огородишную сузиль своимъ насилствомъ [АХУ, III 85, 1631].

Совершаемые насильственные действия могут характеризоваться с использованием наречия нахвально: $и$ m 
[АХУ, III 59, 1628]; и m kии бъ нашими жывоты онъ Яковъ нахвално же завлад қль [АХУ, III 251, 1680].

Для характеристики лиц, совершаемых незаконные действия, используется сочетание учинились силны: И они Нанъ Емельяновъ съ товарыщи твоего государева указу не послушали, учинилися силны [АХУ, III 202, 1652]; тоть архимарить и земские судейки Осипь сь товарыщи... т kхъ моихъ денегъ не плачивали, чинятиа силны [АХУ, III 189, 1646]. Используются и сочетания учинился силен и непослушен, силен и самоволен, после чего следует пояснение более частного характера: И онъ Семенъ твоего великого государя указу учинился непослушенъ, силенъ: соикого и понятыхъ отъ всего отбилъ хл бба и с на записать не даль а хл ббъ перемолотиль и къ себь сносиль и сена перевозиль [АХУ, III 248, 1672]; великого государя грамотамъ чинятия они старизы силны и непослушны [АХУ, III 241, 1665]; И онъ Андрей тое митрополичи грамоть не послушаль, учинился силень и самоволенъ ... и хл ббъ с иеровные земли ... емлеть самоволно, а не по святительскому указу ...[АХУ, III 204, 1653-1654].

Сообщение о нанесенных убытках в документах данного вида может быть представлено довольно устойчивой фразой: и въ томъ мн ъ чинятиа убытки великие [АХУ, III 130, 1635; 147, 1636; 156, 1638; 162, 1639].

Во многих случаях данная формула имеет более распространенный вид. В ее состав вводятся дополнительные сведения, поясняющие причины нанесения убытков. Например: и въ томъ, государь, ихъ насилстве и въ лишномъ окладе и въ наметныхъ денгахъ чинятиа убытки великие [АХУ, III 87, 1631]; и намъ охотничишкамъ въ ихъ нерозплате, въ волоките, въ недопашке, $i$ въ безпромыслище, $i$ въ заемныхъ долгахъ чинятиа убыдки великие [АХУ, III 142, 1636]; i въ томъ, государь, ихъ лишномъ б қлочномъ окладе і въ наметныхъ б қлкахъ чинятся мн ь убытки великия [АХУ, III 76, 1629]; и мнь Сидорку въ его въ Сергиеве изтесненіе і въ насилств 6 въ земляномъ чинятиа убытки великия и недопашка огородишная [АХУ, III 85, 1631]. В челобитной монастырской братии о невыполнении постановления братского собора старцем и священником того же монастыря читаем: $u$ святому м tcmy убытки чинятся великие отъ ихъ вражды [АХУ, III 58, 1628].

Встречаются и варианты данной формулы, где глагол чинятся заменяется глаголом ставятся: і въ томъ его насилств в ставятиа намъ отъ него убытки великие [АХУ, III 64, 1629]; и мнь Мишке оть того брата Олюера ставятиа убытки великие [АХУ, III 113, 1633]. В другом случае в составе формулы наряду с существительным убытки используется существительное изгони: $и$ m tиъ онъ Андр ъй своимъ насилствомъ и озорничествомъ мн $\boldsymbol{b}$ сирот в чинить изгони и убытки великие [АХУ, III 204, 1653-1654].

Нередко сообщение о нанесении убытков связывается с моментом возможной гибели для челобитчика: И мн $\boldsymbol{k}$, государь, въ томъ оть нихъ въ беспромыслии $\mathbf{t}$ въ бесторжиц отъ хозяина своего чинятца многие убытки і въ конеиъ погибаю [АХУ, III 133, 1635]; а язъ сирота въ томь д Ћле погибаю напрасно, и чинятся мн ь убытки великие [АХУ, III 176, 1640]; И я Іванко въ томь от нихъ обнищаль и задолжаль великимъ долгомъ въ ихъ насилстве и въ кон виъ загибъ, деревнишекъ своихъ отсталь въ ихъ неросплатехъ, что ись кабаль изъ ростовъ, изъ убытковъ не вынимаютъ; и въ томъ мн ь отъ нихъ чинятся убытки великия [АХУ, ІІІ 65, 1629].

В некоторых документах стандартная формула о нанесении убытков не употребляется, а звучит лишь мотив гибели челобитчиков и тех отрицательных последствий, к которым привели действия обидчиков. Например: $u$ нын 
з женишкою помираем голодною смертью и до конца загибль [АХУ, III 235, 1662]; $і$ въ томъ я сирота твой отъ нихъ стариовъ з женишкою и з д қтишками помираю по вся дни голодною смертью, до кониа загибль [АХУ, III 241, 1665]; $i$ въ томъ я сирота отъ $m \mathrm{kxъ}$ людеі и оть ихъ великово непослушанья обнищаль и оскудаль, въ конечъ загибль [АХУ, ІІІ 180, 1641]; і оть того, государь, ихъ Яросимова да Леонтьева з братомъ и Іванова оть ихъ вс \$хъ насилства мы сироты твои обдолжали и обсиротали, въ конецъ до основания погибли i твоего государева тягла съ мирскими людми отбыли [АХУ, III 199, 1650]; и ныне я богомолець твой царской отъ того накупного силного человека отъ федора и отъ ево насилства, и оть его ложного челобитья въ хл вбной і въ деревенской недопашке і въ сенной непоставке, $і$ въ скотской гибели съ великихъ убытковъ до кониа загибъ и обдолжаль и з домомъ своимь разорился [АХУ, III 245, 1665]; А мы сироты твои государевы оть его Силина насилства обнищали и задолжали, и въ конецъ загибли, и съ тое деревни твоихъ государевыхъ податей окупать нечемъ и на правеже погибаемъ [АХУ, III 222, 1659]; и меня сироту твоего з д бтишками своими ть въдомые воры Коземка съ товарыщи своимь разбоемъ и воровствомъ до конца погубили [АХУ, III 229, 1660].

Фрагменты аналогичного содержания могут иметь и разговорный характер: $i$ оть того ихъ насилства въ запасной недокупке монастырь нашъ скуд ъеть $i$ братья голодомь помирають [AХУ, III 221, 1659]; $i$ нын ' я б бдная до кониа загибла: по вся дни плачю, нага и боса, и помираю голодною смертью, и къ иеркви Божиі выти помолитиа Богу стало не въ чемъ, и побраль онъ мужь мой у меня б бдные платьишко мое и статки [АХУ, III 225,

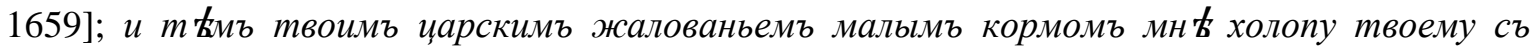
бъдною вдовою съ матушкою и съ людишками прожить и прокормиться не возможно, и передъ своею братьею оскорбленъ [АИ, III 243].

Фрагменты содержательной части челобитной, включающие в себя описания побоев, отличаются значительным разнообразием. Однако и здесь можно выделить довольно устойчивые языковые элементы. Активно используется сочетание глаголов бить и увечить (изувечить): и он, старец, за то нас, сирот своих, бил и увечил, и головын нам пробил до руды [КЧ № 36]; и в паперти, государи, учали с ним, Иваном, о торгах и о промыслах считатись. И тот Иван учал меня бить и увечить, и по щекам кулаки бил, и с ног збил [КЧ 116]; а насъ, господа, тотъ Посникъ биль и изув тчиль на в бкъ [АХУ, II CCLIII 1608]; и как я, государи, пошел из паперти вон, и тот Иван Мизя в дверях папертных бросился на меня и с ног збил, и в лежач учал бить и топтуны топьтать, и изувичил долконща [КЧ 118].

Также используются выражения голову пробить до крови (до руды): пришел он, Стефан, вызвал меня, сироту, в поле и почал меня колом бить и увечить и голову пробил до крови, плечо и руку избил до синов [КЧ 130]; бороду драть (выдрать): биль меня сироту и бороду драль [AXУ, II CCCLXII 1657]; биль онъ Матюей меня, сироту твою, и ув бчиль нахвално, и окровавиль, и головою моею въ трапезную ст бну стукаль, и бороду выдрал [AXУ, II CLXXXI 1674]; за горло давит t: и они за те мои слова, что я их от дурна унимал, стали меня бить и за горло давить [КЧ, 227]; и за волосы драли, и за горло давили [КЧ, 194 1676].

В некоторых случаях такого рода фрагменты носят разговорный характер: $u$ mom Григорей стал ногами топать и харкать и в глаза мне плевать. И по щеке меня ударил неведомо за что. И брат мои Иван Мизя тово Григоря прочь отпехнул [КЧ, 117].

Просительная часть явочных челобитных включала в себя просьбу о регистрации документа. Однако наряду с традиционной формулой вели, государь, мое челобитье и явку 
записать встречаются варианты: и вамъ бы въ томъ было явно и в ъдомо [АХУ, II 118 1579]; и вамъ бы, господа, было явно и в ъдомо [АХУ, II 720 1634]. Рассматривая вариативность формул заключительной части, С.С. Волков отмечал, что «обилие вариантов формул просительного раздела свидетельствует и о меньшей обученности, профессиональности авторов (писцов), писавших эти акты, а следовательно, о большем проявлении здесь стихии разговорной речи, и о стремлении авторов и писцов с помощью отступления от трафаретов добиться большего воздействия на адресата, побудить его к выполнению просьбы». [Волков 1972: 93]. Такую точку зрения подтверждает и А.П.Майоров: «Действительно, такие формулы, как и вам бы, господа, моя явка и нужа была явна и в ведомее; люди добрые, послышьте; посльшьте, бога ради достаточно близки к синтаксису разговорной речи, а в последних формулах наблюдается не свойственная деловой речи экспрессивная окраска» [Майоров 1987: 6].

Формула конечного протокола в целом выдерживалась в рамках приказной письменной традиции: иарь государь, смилуйся, пожалуй. Однако в северновеликорусских челобитных встречаются вариантыразговорного характера: такова, господа моея, явка наша [AХУ, II 527 1600].

На наш взгляд, использование элементов народно-разговорной речи в деловых текстах навряд ли можно объяснить малограмотностью, недостаточной выучкой писцов. Как правило, использование иностилистических языковых средств обусловлено определенными причинами, в том числе информативного свойства (в тех случаях, когда необходимо внести дополнительные пояснения, сведения, для обозначения которых каких-либо специальных формул не предусмотрено). Часто разделить «обработанную» и «необработанную» речь невозможно - письменная фиксация есть сама по себе уже ее обработка. Важно принять во внимание то обстоятельство, что текст делового содержания может отражать речевой акт в его устной форме - интонацию, синтаксическую структуру устного высказывания, содержать разговорные слова, но вместе с тем данный текст в полной мере может представлять деловую речь как функциональную разновидность языка. Кроме того, фрагменты разговорного характера (в частности, казусного раздела челобитных) включают в себя формулы, элементы, характерные для деловой речи. Со всей очевидностью здесь проявляется стремление к единообразию и устойчивости.

Таким образом, можно сделать вывод о сложном взаимодействии делового языка и народно-разговорной речи в документах данного вида. Формирование узуальных норм делового языка XVII века происходило при значительном влиянии и авторитете центральных приказов, что нашло отражение в оформлении документов и использовании языковых средств. 


\section{Литература:}

1. Волков С.С. 1972 Лексика русских челобитных XVII века. Ленинград.

2. Майоров А.П. 1987 Явочные челобитные как памятники русского языка XVI - XVII в.в. Автореферат диссертации кандидата филологических наук. Москва.

\section{Список сокращений:}

АИ - Акты исторические. Сибр. и изд. Археографической комиссиею. Т. I - III, СПб, 1841, т. IV, СПб, 1842.

АХУ - Акты Холмогорской и Устюжской епархии. Ч. I - III, РИБ, т. 12, 14, 25. СПб, 1890 1908.

АЮБ - Акты, относящиеся до юридического быта древней России. Изд. Археографической комиссией под ред. Н. Калачова. Т. I - III. СПб., 1857-1884.

ГААО - Государственный архив Архангельской области.

КЧ - Крестьянские челобитные XVII века. Из собраний Государственного Исторического музея. М: Наука, 1994.

МДБТ - Московская деловая и бытовая письменность XVII века. М., 1968. 